\title{
Recenzja
}

\section{Jakub Bożydar Wiśniewski, The Economics of Law, Order, and Action. The Logic of Public Goods, Routledge Advances in Heterodox Economics, London 2018.}

The book is a general critique of a widely popular premise advanced in the mainstream economics that public goods are an inevitable domain of the state, which, employing the language of the author, can be fancifully called "territorial monopoly of force". The book's underpinning argument is that neoclassical economics is deeply flawed as it suggests that state, who wields monopoly on violence, is not only a preordained, but a very much desired provider of public goods. In his book, Wiśniewski puts under scrutiny two most "paradigmatic" goods in the discourse, notably defense and law. He appears to be very sympathetic to anarchistic views to the point of endorsing them, proposing voluntary arrangements along with polycentric environment, where such goods might be supplied organically, in a bottom-up fashion, without a coercion from an external agency. Wiśniewski is no doubt radical in his ideas. He, for instance, claims that state is not only an inferior supplier of goods (relative to free markets), but actually deprives them of their goods-character. He also views free market as the only legitimate public good. Before analysing feasibility of such a venture with regards to two mentioned goods, he goes on to demolish the very idea of a public good, claiming that there is no reason whatsoever why one should hold such a concept dear.

The theory of public goods was pioneered by Paul Samuelson (Samuelson 1954; Samuelson 1955), who has been widely hailed as a godfather of the concept, and Richard Musgrave (Musgrave 1959), whose contribution to the field has been somewhat obscured by Samualson's fame (Wiśniewski sadly proves this point as he fails to mention this name either), but in fact is sometimes seen as even more influential (Desmarais-Tremblay 2014; Pickhardt 2006). Public goods can be best defined based on what they are not. Firstly, they are not rivalrous; that is to say that consumption of a public good by one person does not diminish nor hinder the full consumption of that good by another person. Secondly, they are not excludable, meaning once the good has been provided it is impossible (or impractical, e.g. too expensive) to exclude other people from consuming it, which leads to a problem of free-riding (see below).

Wiśniewski choses to focus his analysis on two types of public goods - common goods and club good. It seems to be a right decision as pure public goods (goods exhibiting two properties simultaneously) are extremely rare in real life - they are rather considered as being unicorns or "mythical beasts" to quote Cornes and Sandler (Cornes and Sandler 1994). Textbook examples of such goods include a lighthouse, clean air, an unpatented knowledge or a road sign. Importantly, public goods have been around for a long time before Paul Samuelson. Both David Hume and Adam Smith had alluded to their existence (Cornes and Sandler 1986, 3; Musgrave and Musgrave 2003). Various public goods were in use in medieval times (Desai 2003). In fact, the "publicness" of goods often predated their "privateness". Although the theory of public goods outlined by Samuelson is 
somewhat technical and subject to mathematical rigor, for which Samuelson had been criticized (Enke 1955), scholars have long argued that their characteristics are not carved in stone. Most famously, James Buchanan has advocated for an alternative view of public goods, arguing that they are merely "goods demanded and supplied through political institutions" (Buchanan 1968, 5). Having said that, whether a good is public or not is subject to collective demand, the political process and negotiations within the society. Furthermore, many goods "become" public instead of just "being" public, which makes them somewhat of a social construct and hinged on an institutional context. For this and other reasons, a division between private and public goods is often considered "a false dichotomy" (Grayson 2001, 235). In a similar vein, yet with a different conduct, very much in the spirit of the article of Malkin and Wildavsky (1991), the Author criticizes the notion of public goods as arbitrary and, in many instances, artificial. In his view, the only truly legitimate public good is free market, others phenomena are ill-conceived inventions of academics. Wiśniewski makes an interesting point that excludability is not an inherent feature of public goods or any good for that matter, but a function of entrepreneurial inventiveness. This brings to mind an example of the lighthouse, which is routinely used to illustrate theoretical properties of public goods. However, as Ronald Coase famously points out, in the past lighthouses had been operated in Great Britain by private agents and it had not only been feasible but also quite an effective institutional setup (Coase 1974).

Coming from the public goods academic camp myself, it appears to me that the concept gets sometimes mixed up with another type of goods, notably merit goods (also courtesy of Richard Musgrave), or at least those two categories are not sufficiently delineated. The latter is typically private goods that are supplied by public institutions (or funded from public money) to the benefit of oftentimes unknowing consumers (Wiśniewski would rather use the term "coerce" and point to their unhappy end-users instead of happy or neutral). Mandatory public education, vaccines or subsidized vegetables in school canteens may be examples of those. Therefore, whether public goods usually have at least one theoretical property - either non-rivalrousness or non-excludability (or both in the extremely rare case of pure public goods) - merit goods are free from this assumption (another distinction is that they are consumed individually rather than collectively). This renders them theoretical orphans of sorts, but also may provide a twist to the public goods discourse.

The book comprises of six chapters, with certain parts drawing on articles published by the Author in various academic journals. The last chapter is distinctive, as it uses ethical lenses, whereas the previous present an economic viewpoint, even if philosophical traces are ubiquitous. The book is very dense and the multiplicity of arguments would make its comprehensive summary a virtually impossible endeavour. The way the Author navigates the immense body of literature and steers the discussion throughout the volume is commendable. Although clearly sympathetic to the libertarian thinking, he is not blind to arguments that go beyond this intellectual framework or even challenge it outright, even though Wiśniewski shies away from academic big names (see Stiglitz) whose endorsement of public goods and their provision by the state is well-know and might upset his reasoning. He offers myriad of examples to make his point, among which the theatre reductio ad absurdum is my favourite in Chapter 2 and seriously engage with counter-arguments, instead of just dismissing them from the position of intellectual superiority.

I particularly enjoyed the chapter on defense which he breaks down into short-, mid- and longrange. This helps to address the complexity of defense and different sets of obstacles associated with them. In terms of long-range protection goods, the examples of Switzerland and Liechtenstein, as countries never invaded because of their lucrative trading potential seem to be slightly misplaced. One could name a number of other countries, with equally lucrative potential, that nevertheless have been "targets for war", some even driven to near annihilation. Importantly, the "publicness" of national defense has been challenged by many authors earlier. Defense may be conceptually considered a public good, yet the material resources required to make it work are very much limited and subject to rivalry; it may be also excludible in a sense that certain parts of the territory invaded can be more exposed to risk than others, thus making them more difficult to protect. The discussion 
of free-riding, a fundamental problem pertaining to defense, could additionally benefit from the work of Mancur Olson (1965), who argues that the scale of free-riding hinges of the sheer number of individuals involved (in smaller groups free-riding is rarely an issue, whereas in big groups it usually thrives).

To book strives for intellectual rigour. For a regular reader, without prior exposure to the subject, it can be a quite heavy burden, as the language Wiśniewski uses knows no mercy. Persons not familiar with terms such as praxeology, thymology or polycentrism will have to do their home-work first, before they can appreciate the elevated if not slightly hermetic language. Once they have accomplished that they can move on to contemplate the underpinning research question - can public goods be effectively produced in the absence of institutional coercion, by the force of free markets and a voluntary behaviour of individuals? The author claims that they can and, in some cases, they actually are. His writing is radical with radical implication, yet at the same time it is writing highly stimulating. Even for those who vehemently disagrees with the Author's points, it will be surely an entertaining and a worthwhile read.

\section{References}

Buchanan, J. (1968). The Demand and Supply of Public Goods. Chicago: Rand McNally.

Coase, R.H. (1974). The Lighthouse in Economics. Journal of Law and Economics, 17 (2), 357-376.

Cornes, R., Todd, S. (1994). Are Public Goods Myths? Journal of Theoretical Politics, 6 (3), 369 385.

Desmarais-Tremblay, M. (2014). On the Definition of Public Goods, Assessing Richard A. Musgrave's Contribution, CES Working Paper 4, Universite Paris, 1.

Enke, S. (1955). More on the Misuse of Mathematics in Economics: A Rejoinder. Review of Economics and Statistics, 37 (2), 131-133.

Grayson, K. (2001). Human Security in The Global Era. In D. Drache (ed.), The Market Or the Public Domain?: Global Governance and the Asymmetry of Power, New York: Routledge.

Malkin, J., Wildavsky, A. (1991). Why the traditional distinction between public and private goods should be abandoned, Journal of Theoretical Politics, 3 (4), 355-378.

Musgrave, R. (1959). The Theory of Public Finance: A Study in Public Economy, New York: McGraw-Hill.

Musgrave, R.A., Musgrave, P.B. (2003). Prologue in Advancing the Concept of Public Goods. In Inge Kaul et al. (eds.). Providing Global Public Goods. Managing Globalization. New York: Oxford University Press.

Olson, M. (1965). The Logic of Collective Action, Public Goods and the Theory of Groups, Cambridge: Harvard University Press.

Pickhardt, M. (2006). Fifty Years after Samuelson's “The Pure Theory of Public Expenditure": What are we Left With? Journal of the History of Economic Thought, 28 (4), 439-460.

Samuelson, P. (1954). The Pure Theory of Public Expenditure. The Review of Economics and Statistics, 36, 387-389.

Samuelson, P. (1955). Diagrammatic Exposition of a Theory of Public Expenditure. Review of Economics and Statistics, 37, 350-356.

Dominik Kopiński

University of Wroclaw

Ekonomia - Wroclaw Economic Review 26/1, 2020

(C) for this edition by CNS 